\title{
KONSEP EKOLOGIS DAN BUDAYA PADA PERANCANGAN HUNIAN PASKA BENCANA DI YOGYAKARTA
}

\author{
Lucky Prasetyo, Rumiati R. Tobing, Hartanto Budiyuwono \\ Magister Arsitektur, Program Pascasarjana, Universitas Katolik Parahyangan, Bandung \\ Jl. Merdeka, No. 30, Bandung - Indonesia \\ Email: prasetyolucky88@gmail.com
}

\begin{abstract}
Abstrak
Hunian bantuan pasca bencana biasanya didesain dengan desain yang hanya mempertimbangkan kecepatan konstruksi dan efisiensi biaya pembangunan dengan kurang mempertimbangkan kekhasan budaya lokal serta kondisi lingkungan suatu kawasan. Bila hal ini terjadi secara terus menerus, maka arsitektur lokal yang merupakan wadah dari budaya lokal dan bentuk respon masyarakat terhadap kondisi lingkungan sekitar secara perlahan akan terancam hilang bersamaan dengan adanya bencana, yang kemudian akan tergantikan dengan bentuk-bentuk hunian yang hampir seragam disemua tempat. Penelitian ini bertujuan untuk mengidentifikasi konsep ekologis dan budaya pada perancangan hunian paska bencana di desa Ngibikan yang berhasil menjawab kebutuhan penghuninya dan menyatu dengan kehidupan masyarakatnya. Metode yang digunakan adalah metode kualitatif deskriptif untuk menggali konsep ekologi dan budaya pada perancangan di desa Ngibikan.Berdasar hasil penelitian didapatkan bahwa penerapan konsep ekologis dan budaya pada perencanaan desain hunian paska bencana di desa Ngibikan turut mempengaruhi keberhasilan desain dalam menjawab kebutuhan penghuni dan merespon kondisi alamnya. Diharapkan proses rekonstruksi pemukiman paska bencana di desa Ngibikan ini dapat menjadi contoh bagi proses rekonstruksi dimasa mendatang agar proses rekonstruksi tidak hanya berupa upaya memenuhi kebutuhan hunian bagi korban bencana namun juga suatu upaya melestarikan arsitektur lokal yang merupakan wadah dari budaya lokal dan bentuk respon masyarakat terhadap kondisi lingkungan di suatu kawasan.
\end{abstract}

Kata kunci: hunian, paska bencana, rekonstruksi, ekologis, budaya lokal

\begin{abstract}
Title: Ecologicals and Culture Concepts in Post-Disasters Housing Design

Post-disaster housing is usually designed with a design that considers only the rapidity of development and cost efficiency without thinking of local cultural and environmental conditions of an area. If this happens continuously, then the local architecture which is a container of local culture and the form of community response to the surrounding environment will slowly be threatened to disappear along with the disaster, which will then be replaced by almost uniform shelter in all places. This study aims to identify ecological and cultural concepts on post-disaster residential design in Ngibikan village that successfully responds to the needs of its inhabitants and blends with the lives of its people. The method used is descriptive qualitative method to explore the concept of ecology and culture on the design in Ngibikan village. Based on the results of the research, it is found that the application of ecological and cultural concepts in the design of post-disaster residential design in Ngibikan village also influenced the success of the design in responding to the needs of the residents and responding to the natural conditions. It is expected that the post-disaster reconstruction process in Ngibikan village can serve as an example for the reconstruction process in the future so that the reconstruction process will not only be an effort to fulfill residential needs for disaster victims but also an effort to preserve local
\end{abstract}


architecture which is a container of local culture and form of community response to the condition environment in an area.

Keywords: housing, post-disaster, reconstruction, ecological, local cultural

\section{Pendahuluan}

Sebagian besar kawasan Indonesia merupakan kawasan rawan bencana, dimana dalam setiap bencana alam banyak menimbulkan banyak korban jiwa dan kerugian material \& non material(https://www.bnpb.go.id/home/p otensi diakses pada November 2017). Dalam setiap bencana alam, terdapat pemberian bantuan hunian yang diberikan pemerintah, donatur swasta ataupun LSM kepada masyarakat korban bencana yang kehilangan hunian. Hunian bantuan paska bencana yang dibangun dengan sistem tender (topdown) biasanya didesain hanya mempertimbangkan kecepatan konstruksi dan efisiensi biaya pembangunan serta kurang mempertimbangkan kekhasan budaya lokal penghuni, kondisi lingkungan di suatu kawasan, serta bentuk arsitektur lokal pada suatu daerah untuk menunjang keberhasilan proses rehabilitasi masyarakat korban bencana (https://berkota.wordpress.com/2012/07/ 18/komunikasi-arsitektural-pascabencana/ diakses pada November 2017). Bila hal ini terjadi secara terus menerus, maka arsitektur lokal secara perlahan akan terancam hilang bersamaan dengan adanya bencana, yang kemudian akan tergantikan dengan bentuk-bentuk hunian paska bencana yang sama dan hampir seragam disemua tempat dan tidak mencerminkan budaya, iklim dan arsitektur lokal yang merupakan wadah bagi budaya/kebiasaan masyarakat setempat dan respon penghuni terhadap iklim dan sumber daya lokal (ekologi) yang ada pada lingkungan sekitarnya yang sudah terbukti bertahun-tahun secara turun temurun (Schultz,1980).

Oleh karena itu, membangun hunian paska bencana yang memiliki pendekatan desain pada budaya lokal dan ekologi merupakan suatu upaya melestarikan arsitektur lokal yang ada di Indonesia dari ancaman bencana dan pemberian bantuan yang kurang memperhatikan unsur budaya masayarakat calon penghuninya, selain memenuhi kebutuhan korban bencana alam akan hunian yang layak.

Salah satu contoh kasus proses rekonstruksi hunian paska bencana yang menggunakan pendekatan budaya dan ekologi adalah proses rekonstruksi di desa Ngibikan, Kabupaten Bantul, Yogyakarta yang diinisiasi oleh arsitek Eko Prawoto pada 2006. Proses rekonstruksi di desa Ngibikan yang terdiri dari 65 rumah ini di desain untuk menggunakan bentuk arsitektur lokal dan memanfaatkan potensi yang ada seperti penggunaan material ulang dan daur ulang serta penggunaan proses partisipatif masyarakat untuk menjawab kebutuhan masyarakat serta agar desain dapat menyatu dengan kehidupan masyarakatnya (Shim ,2010). Proses rekonstruksi pemukiman ini dinilai berhasil karena selain dapat menjawab kebutuhan penghuninya juga, responsif terhadap lingkungan sekitarnya serta dapat mempertahankan nilai-nilai budaya masyarakatnya. Keberhasilan 
proses rekonstruksi ini dapat dilihat dari kondisi setelah pemukiman ini dihuni selama 10 tahun dengan transformasi bentuk yang minimal dan selaras dengan bangunan aslinya.

Tujuan dari dibuatnya jurnal ini adalah untuk mempelajari sejauh mana konsep ekologis dan budaya yang diterapkan dalam perancangan hunian paska bencana di desa Ngibikan Yogyakarta. Dengan mengetahui penerapan konsep ekologis dan budaya pada perancangan hunian paska bencana, diharapkan jurnal ini dapat digunakan sebagai bahan pertimbangan dalam perancangan hunian paska bencana dikemudian hari yang tidak hanya mengedepankan kecepatan pembangunan dan efisiensi biaya saja, namun lebih dapat mewadahi budaya/kebiasaan penghuninya, memelihara keberlangsungan arsitektur lokal serta responsif terhadap lingkungan dimana bangunan tersebut berdiri.

\section{Konsep Ekologi dalam Desain Arsitektur}

Konsep Ekologi merupakan konsep penataan lingkungan dengan memanfaatkan sumberdaya alam yang ada dan penggunaan teknologi secara etis untuk mendapatkan desain Arsitektur yang ramah Lingkungan. Pola perencanaan Arsitektur Ekologis/EkoArsitektur pada daerah tropis adalah sebagai berikut:

Elemen-elemen arsitektur mampu seoptimal mungkin memberikan perlindungan terhadap sinar panas, angin dan hujan.

Intensitas energi yang terkandung dalam material yang digunakan saat pembangunan harus seminimal mungkin, dengan cara-cara:

1. Perhatian pada iklim setempat
2. Substitusi, minimalisasi dan optimasi sumber energi yang tidak dapat diperbaharui

3. Penggunaan bahan bangunan yang dapat dibudidayakan dan menghemat energi

4. Pembentukan siklus yang utuh antara penyediaan dan pembuangan bahan bangunan, energi, atau limbah dihindari sejauh mungkin

5. Penggunaan teknologi tepat guna yang manusiawi

Pendekatan ekologi dalam arsitektur yang lain yaitu menurut Frick (1998) adalah bahwa eko-arsitektur mencakup keselarasan antara manusia dan alam. Eko-arsitektur mengandung juga dimensi waktu, alam, sosio kultural, ruang dan teknik bangunan. Ekoarsitektur bersifat kompleks, oleh sebab itu eko-arsitektur bersifat holistik dan berkaitan dengan semua bidang.

Pada cakupan yang lebih luas, Cowan dan Ryn (1996) mengemukakan prinsipprinsip desain yang ekologis sebagai berikut:

1. Solution Grows from Place: solusi atas seluruh permasalahan desain harus berasal dari lingkungan di mana arsitektur itu akan dibangun. Prinsipnya adalah memanfaatkan potensi dan sumber daya lingkungan untuk mengatasi setiap persoalan desain. Pemahaman atas masyarakat lokal, terutama aspek sosial-budayanya juga memberikan andil dalam pengambilan keputusan desain. Prinsip ini menekankan pentingnya pemahaman terhadap alam dan masyarakat lokal. Dengan memahami hal tersebut maka kita dapat mendesain lingkungan binaan tanpa menimbulkan kerusakan alam maupun 'kerusakan' manusia. 
2. Ecological Acounting Informs Design: perhitungan-perhitungan ekologis merupakan upaya untuk memperkecil dampak negatif terhadap lingkungan. Keputusan desain yang diambil harus sekecil mungkin memberikan dampak negatif terhadap lingkungan.

3. Design with Nature: arsitektur merupakan bagian dari alam. Untuk itu setiap desain arsitektur harus mampu menjaga kelangsungan hidup setiap unsur ekosistem yang ada di dalamnya sehingga tidak merusak lingkungan. Prinsip ini menekankan pada pemhaman mengenai living process di lingkungan yang hendak diubah atau dibangun.

4. Everyone is a Designer: melibatkan setiap pihak yang terlibat dalam proses desain. Tidak ada yang bertindak sebagai user atau participant saja atau designerl arsitek saja. Setiap orang adalah participant-designer. Setiap pengetahuan yang dimiliki oleh siapapun dan sekecil apapun harus dihargai. Jika semua orang bekerjasama untuk memperbaiki lingkungannya, maka sebenarnya mereka memperbaiki diri mereka sendiri.

5. Make Nature Visible: proses-proses alamiah merupakan proses yang siklis. Arsitektur sebaiknya juga mampu untuk melakukan proses tersebut sehingga limbah yang dihasilkan dapat ditekan seminimal mungkin.

Sejalan dengan Cowan dan Ryn, Hui (2001) melengkapi prinsip tersebut di atas dengan mengemukakan prinsip understanding people yang intinya pada upaya memahami konteks budaya, agama, ras, perilaku, dan kebiasaan (adat) masyarakat yang akan diwadahi oleh arsitektur. Prinsip lain yang dikemukakan Hui antara lain adalah :Understanding Place, Connecting with Nature, Understanding Natural
Processes,

Understanding

Environmental Impact, serta Embracing Co-creative Design Processes.

Dalam penerapannya di Indonesia, teoriteori desain ekologis di atas harus dipahami dalam kenyataan bahwa arsitektur nusantara merupakan arsitektur yang hidup menyatu dengan lingkungan alam dan lingkungan sosialnya, bukan arsitektur yang bersifat individual.

\section{Konsep Budaya pada Hunian Tradisional}

Menurut Rapoport (1969) dalam buku House Form and Culture yang menjelaskan tentang alternatif bentuk, menjelaskan bahwa ada beberapa hal yang berpengaruh dalam suatu bentuk arsitektur,khususnya hunian tradisional.

Ia menjelaskan bahwa ada beberapa faktor yang mempengaruhi terciptanya suatu bentuk yang terbagi menjadi 2 faktor besar antara faktor primer dan faktor sekunder.

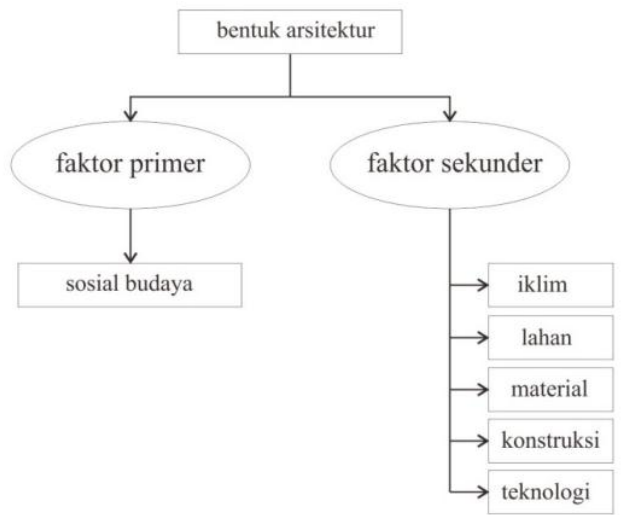

Gambar 1. Faktor yang mempengaruhi bentuk arsitektur

Digambar ulang menurut Rapoport, 1969

Yang termasuk dalam faktor primer adalah faktor sosial budaya. Faktor sosial budaya meliputi agama, kepercayaan, cara hidup, pandangan 
hidup, struktur masyarakat dan keluarga, organisasi masyarakat, serta hubungan kekerabatan antar individu dalam masyarakat. Pandangan hidup setiap orang akan berbeda tergantung dengan hubungan antar individunya. Oleh karena itu, dapat dikatakan faktor sosial budaya merupakan salah satu hal yang khas yang membedakan antara kebudayaan satu dengan kebudayaan lain. Budaya menentukan cara hidup, kebiasaan dan tingkah laku tiap individu dan cara hidup setiap kelompok masyarakat menentukan bentukan arsitektur maupun pola penataan ruang arsitektur dalam suatu daerah atau kelompok masyarakat. Faktor sosial budaya merupakan salah satu hal yang paling penting dalam proses lahirnya bentuk arsitektur. Hal ini dipertegas oleh Rapoport (1969) dalam pernyataannya sebagai berikut:"My basic hypothesis, then, is that house form is not simply the result of physicalforces or any single causal factor, but is the consequence of a whole range of sosio-cultural factors seen in their broadest terms. Form is in turn modified by climaticconditions (the physical environment which makes some things impossible and encourages others) and by methods of construction, material available, and the technology (the tools for achieving the desired environmenO. I will call the sosiocultural forces primaiy, and the others secondary or modifying ". Senada dengan Rapoport, Knapp dan Lo (2005) menyatakan sebagai berikut: "Houses are more than just physical structures and in all societies relate closely to social groups and cultural identities ".

Hal ini dapat dilihat dari ditemukannya berbagai macam bentuk arsitektur tradisional walaupun dalam kawasan yang memiliki kemiripan kondisi iklim ataupun topografi. Rumah Bolon di batak Toba berbeda bentuk dengan Rumah Batak Karo. Dan bila dilihat pada cakupan area yang lebih luas maka akan ditemukan lebih banyak beragam bentuk hunian walaupun berada pada kawasan tropis yang sama. Hal ini membuktikan bahwa faktor sosial budaya merupakan faktor utama yang mempengaruhi bentuk arsitektur hunian masyarakat tradisional.

\section{Konsep Bentuk Hunian Tradisional Nusantara}

Menurut Prijotomo (2010), esensi dari arsitektur nusantara adalah arsitektur pernaungan bukan arsitektur perlindungan yang tertutup dan terlindungi dengan dinding masif atau berbentuk panggung. Bentuk hunian panggung merupakan salah satu variasi yang diterapkan pada satu jenis hunian tradisional, namun pada intinya arsitektur Nusantara adalah arsitektur pernauangan, yang melindungi penghuninya dari kondisi iklim panas dan hujan yang ekstrim. Sehingga dapat dikatakan bahwa arsitektur nusantara adalah arsitektur atap, dimana atap bukan hanya sekedar mahkota atau kepala namun juga elemen terpenting dalam arsitektur nusantara.

Beberapa alasan yang menguatkan bahwa elemen atap merupakan elemen pernaungan yang paling penting pada arsitektur nusantara antara lain adalah :

1. Faktor kelembaban udara dan angin yang harus diatasi dengan desain bangunan yang terbuka / berpori-pori sehingga angin dapat leluasa masuk ke dalam bangunan untuk mengurangi kelembaban udara di dalam bangunan

2. Faktor musim panas dan penghujan dimana bentuk atap dengan ruang 
dibawah atap yang besar untuk menghindari radiasi panas turun ke ruang dalam serta teritis yang lebar sangat baik untuk menghindari tampias air hujan.

3. Arsitektur dengan konstruksi yang tahan gempa mengingat indonesia merupakan kawasan rawan gempa.

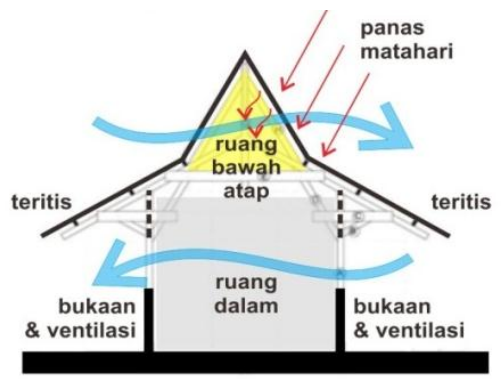

Gambar 2. Faktor yang mempengaruhi bentuk arsitektur nusantara

\section{Metode Penelitian}

Pembahasan studi kasus dilakukan dengan metoda kualitatif dengan pendekatan deskriptif Penelitian kualitatif ini dipilih karena dapat mengamati obyek studi lebih mendalam. Penelitian deskriptif digunakan untuk mendapatkan gambaran mengenai kondisi pemukiman di desa Ngibikan dalam mewadahi kebutuhan dan budaya masyarakatnya.

Dalam penelitian dibutuhkan data yang menunjang hasil penelitian yang didapat dari hasil observasi langsung dilapangan untuk mendapatkan data berupa foto dan gambar lapangan. Selain itu untuk mendapatkan informasi yang lebih mendalam terkait penelitian, dilakukan wawancara terhadap beberapa penghuni di desa Ngibikan untuk mengetahui pengalaman penghuni dan tingkat kepuasan penghuni, terkait pemenuhan kebutuhan, kemudahan proses adaptasi, kenyamanan hunian serta kemudahan dalam perbaikan dan pengembangan bangunan, terhadap desain hunian yang mereka tinggali. Disamping itu diperlukan beberapa data sekunder yang berupa literatur untuk menggali informasi dan data selama proses rekonstruksi di desa Ngibikan ini berlangsung.

\section{Hasil dan Pembahasan}

\section{Konsep Ekologis pada desain Hunian paska bencana di desa Ngibikan}

Konsep ekologis yang dapat ditemukan dalam desain hunian paska bencana di desa Ngibikan, sesuai dengan yang dikemukakan oleh Cowan dan Ryn (1996) antara lain:

\section{Solutions Grows from Place}

Untuk mendapatkan desain yang sesuai dengan kebutuhan penghuninya, arsitek berusaha menggali kebiasaan hidup masyarakat dengan proses diskusi dan mempelajari aristektur lokal setempat yang diyakini merupakan wadah yang paling cocok bagi kehidupan masyarakat setempat.
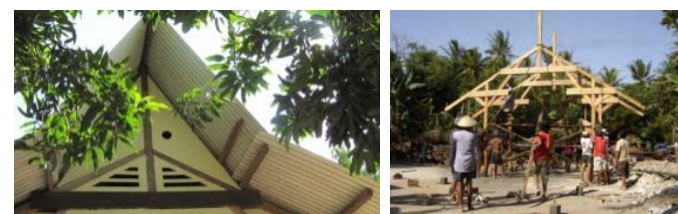

Gambar 3. Pemanfaatan potensi lokal seperti penggunaan arsitektur lokal, material lokal serta gotong royong dalam pembangunan Sumber: www.slideshare.net pada November 2016

Pola tatanan masa yang sudah terbentuk secara alami dipertahankan agar sesuai dengan pergerakan masyarakat. Penggunaan material lokal dan daur 
ulang serta pembangunan dengan sistem gotong royong merupakan beberapa upaya untuk memaksimalkan potensi lokal yang ada.

2. Ecological Acounting Informs Design Desain hunian paska bencana di desa Ngibikan tidak menggunakan perhitungan-perhitungan kuantitatif tentang penggunaan energi dan ekologi, namun dalam beberapa keputusan desain tetap memperhitungkan tentang dampak lingkungan dan penghematan energi secara tidak langsung. Pembangunan menggunakan material daur ulang merupakan salah satu upaya untuk mengurangi sampah dari reruntuhan bangunan lama. Dengan berkurangnya sampah dari reuntuhan akibat gempa, maka efek negatif menumpuknya sampah bagi lingkungan dapat dikurangi. Selain itu, bangunan di desa Ngibikan ini didesain dengan memanfaatkan cahaya dan udara alami semaksimal mungkin sehingga penggunaan listrik dan bahan bakar fosil untuk listrik dapat dikurangi.
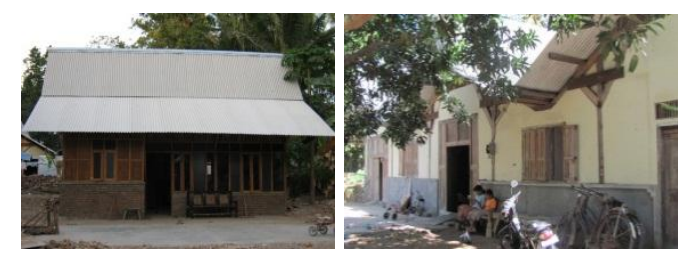

Gambar 4. Pemanfaatan material daur ulang yang membuat tiap rumah memiliki tampilan berbeda

Sumber: www.slideshare.net pada November 2016

\section{Design with Nature}

Hunian di desa Ngibikan ini dibangun di atas reruntuhan rumah lama. Selain untuk mempermudah kepemilikan lahan, juga bertujuan untuk mempertahankan ruang hijau dan pepohonan yang ada di kawasan. Selain itu, hunian di desa Ngibikan didesain dengan bentuk bangunan lokal setempat yang sangat responsif terhadap kondisi iklim setempat tanpa harus mengandalkan pencahayaan dan sistem pengudaraan buatan untuk mendapatkan kenyamanan di dalam ruang. Selain itu, hunian hasil rekonstruksi di desa Ngibikan ini didesain menggunakan material lokal yang ada disekitar dengan tujuan untuk memudahkan masyarakat dalam melakukan perbaikan atau penggantian material di kemudian hari. Penggunaan material lokal juga mendorong masyarakat untuk menjaga kelestarian sumber material seperti pohon-pohon lokal penghasil kayu ataupun bambu.

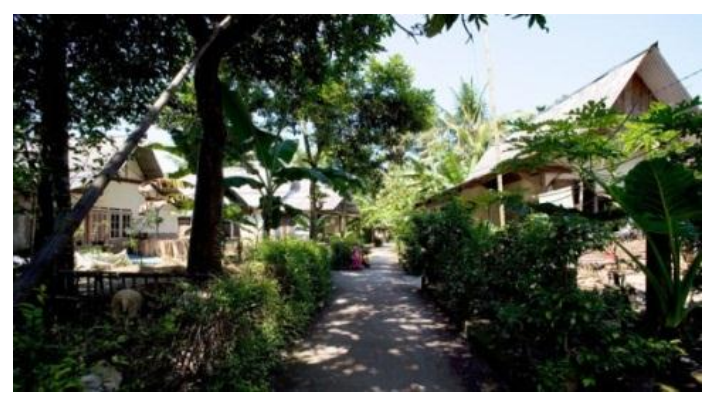

Gambar 5. Ruang-ruang luar, pepohonan dan kondisi lingkungan yang dipertahankan

Sumber: www.akdn.org pada November 2016

\section{Everyone is a Designer}

Proses rekonstruksi pemukiman di desa Ngibikan ini dilakukan dengan melibatkan masyarakat penghuninya secara aktif dari proses perencanaan sampai proses pembangunan.

Proses pembangunan partisipatif ini bertujuan untuk mengetahui kebutuhan penghuni sehingga desain yang dihasilkan dapat tepat guna bagi penghuninya.

Arsitek pada proses rekonstruksi ini tidak diposisikan sebagai seorang 
penentu kebijakan proyek, namun lebih pada fasilitator pendamping bagi masyarakat. Dengan metode ini, didapatkan hasil rekonstruksi yang sesuai dengan kebutuhan masyarakat. Hal ini dapat dilihat dari pertumbuhan bangunan setelah 10 tahun dihuni, dimana perkembangan bangunan berjalan selaras dengan desain hunian inti.
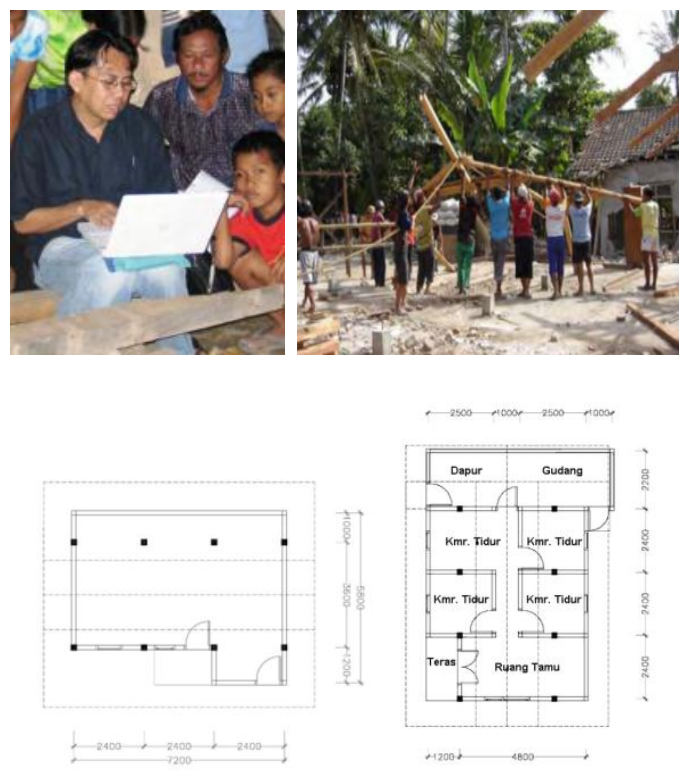

Gambar 6. Proses diskusi arsitek dengan warga, proses gotong royong, serta variasi denah tiap hunian

Sumber: www.akdn.org pada November 2016

\section{Make Nature Visible}

Cara arsitek dan masyarakat untuk merespon kondisi iklim dan geografis desa Ngibikan adalah dengan mengunakan bentuk arsitektur lokal setempat. Bentuk arsitektur lokal dipercaya merupakan cara masyarakat merespon iklim setempat yang telah dilakukan secara turun temurun.

Selain itu, penggunaan material lokal sebagai material utama bangunan merupakan keputusan desain untuk menunjang keberlanjutan. Material lokal seperti bambu dan kayu merupakan material yang mudah terurai bila menjadi limbah. Banyaknya ketersediaan material lokal yang ada disekitar juga bertujuan agar masyarakat mudah dalam melakukan penggantian / pengembangan bangunan, serta mau menjaga lingkungan demi menjaga ketersediaan material bangunan tetap tersedia di lingkungan sekitar.

\section{Bentuk Arsitektural dan Aspek Budaya pada Proses Pembangunan Hunian di Desa Ngibikan}

Desain Hunian bantuan paska bencana yang diajukan dan kemudian disepakati oleh masyarakat desa Ngibikan adalah desain hunian dengan atap tipe Kampung atau yang biasa disebut 'Srotongan' oleh masyarakat setempat. Bentuk ini merupakan bentuk asli hunian di kawasan tersebut.

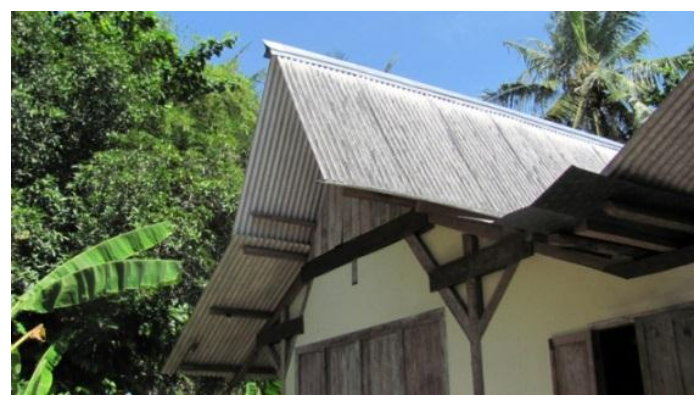

Gambar 7. Atap hunian tradisional tipe kampung

Sumber: www.akdn.org pada November 2016

Desain bangunan baru hasil rekonstruksi sengaja mengambil bentuk lokal setempat dengan alasan agar masyarakat tidak perlu terlalu lama beradaptasi dengan bangunan baru tersebut. Selain itu, bangunan dengan arsitektur lokal oleh arsitek pendamping, Ir. Eko Prawoto, merupakan wadah bagi budaya dan kebiasaan masyarakat secara turun- 
temurun dalam menghadapi kondisi iklim dan lingkungan setempat.
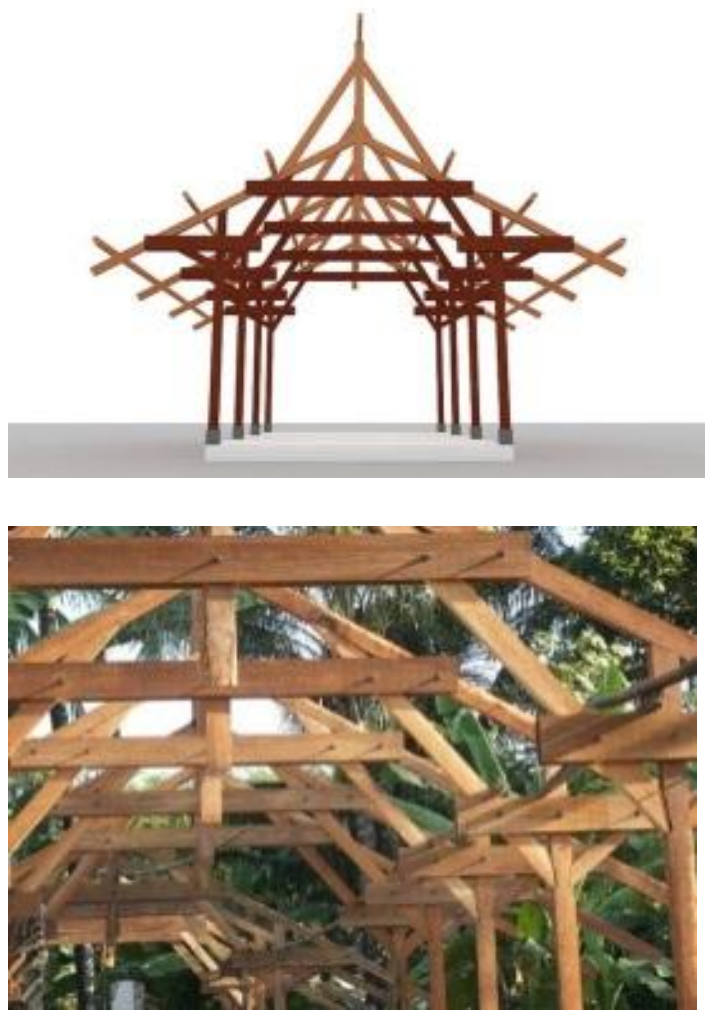

Gambar 8. Struktur rangka modular dengan material lokal dan daur ulang

Sumber: www.akdn.org pada November 2016

Bangunan didesain dengan sistem modul. Sistem modul digunakan untuk mempermudah proses pembangunan dan juga untuk memperoleh fleksibilitas pengaturan ruang di dalamnya. Bangunan dibuat menggunakan modul 1.2 meter dan kelipatannya. Dengan adanya modul ini, konfigurasi ruang dalam bangunan dapat diatur secara lebih fleksibel dan dapat disesuaikan dengan kebutuhan warga yang berbedabeda.

Bangunan baru hasil rekonstruksi dibangun di atas posisi rumah lama sewaktu sebelum terjadi gempa, selain untuk mempermudah pembagian hak kepemilikan juga bertujuan untuk mempertahankan ruang-ruang sosial antar bangunan yang sudah terbentuk secara alami secara turun temurun.

Rumah didesain menggunakan rangka kayu kelapa yang banyak ditemui pada daerah ini dan sisa-sisa kayu bekas rumah lama yang masih dapat digunakan.

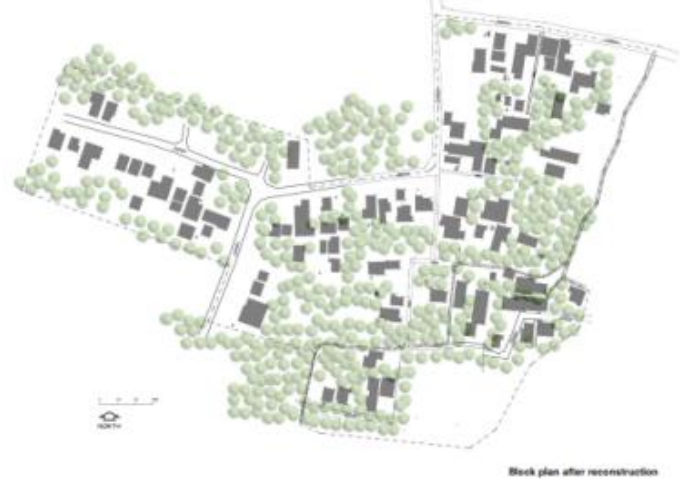

Gambar 9. Pola tata massa asli desa yang dipertahankan dalam proses rekonstruksi

Sumber: www.slideshare.net pada November 2016

Pengerjaan pembangunan dilakukan dengan cara bergotong-royong dengan metode ketukangan lokal yang dipadukan dengan teknik modern. Hal ini dapat dilihat dari bentuk struktur yang tradisional seperti rumah kampung pada umumnya, namun bila dilihat lebih detail sambungan antar struktur menggunakan mur dan baut yang membuat proses pembangunan menjadi lebih cepat. 
Tabel 1. Pengaruh budaya/arsitektur lokal pada elemen arsitektural dari desain hunian di Ngibikan

\begin{tabular}{|c|c|c|c|}
\hline no & $\begin{array}{c}\text { elemen } \\
\text { arsitektural }\end{array}$ & $\begin{array}{l}\text { penggunaan elemen } \\
\text { arsitektur lokal setempat }\end{array}$ & $\begin{array}{c}\text { dampak } \\
\text { positif }\end{array}$ \\
\hline 1 & Tata masa desa & $\begin{array}{l}\text { menggunakan tata masa eksisting desa yang } \\
\text { telah terbentuk secara alami }\end{array}$ & $\begin{array}{l}\text { penduduk telah terbiasa } \\
\text { dengan pola eksisting desa }\end{array}$ \\
\hline 2 & $\begin{array}{l}\text { Bentuk sosok } \\
\text { bangunan }\end{array}$ & $\begin{array}{l}\text { menggunakan bentuk arsitektur lokal- } \\
\text { rumah tipe atap kampung }\end{array}$ & $\begin{array}{l}\text { sesuai dengan budaya \& } \\
\text { iklim setempat }\end{array}$ \\
\hline 3 & $\begin{array}{l}\text { Bentuk \& } \\
\text { tata ruang }\end{array}$ & $\begin{array}{l}\text { kebutuhan ruang tiap keluarga diakomodasi } \\
\text { dalam desain yang berbeda namun sesuai modul }\end{array}$ & $\begin{array}{l}\text { kebutuhan inti tiap keluarga } \\
\text { terpenuhi }\end{array}$ \\
\hline 4 & Material bangunan & $\begin{array}{l}\text { material lokal \& material daur ulang dari } \\
\text { reruntuhan rumah lama }\end{array}$ & $\begin{array}{l}\text { mudah didapat, mengurangi } \\
\text { sampah }\end{array}$ \\
\hline 5 & Struktur bangunan & $\begin{array}{l}\text { struktur lokal (kuda-kuda kayu tradisional) } \\
\text { yang dibuat modular dengan sambungan sekrup }\end{array}$ & $\begin{array}{l}\text { cepat dalam pembangunan } \\
\text { familiar dengan masyarakat }\end{array}$ \\
\hline 6 & $\begin{array}{l}\text { Proses perencanaan } \\
\& \text { Pembangunan }\end{array}$ & $\begin{array}{l}\text { dilibatkan secara aktif dalam musyawarah- } \\
\text { kebutuhan tiap keluarga diakomodasi } \\
\text { partisipasi aktif-gotong royong-transfer ilmu } \\
\text { ketukangan }\end{array}$ & $\begin{array}{l}\text { aspirasi \& kebutuhan } \\
\text { warga terakomodasi } \\
\text { memudahkan proses perbaikan } \\
\text { dikemudian hari }\end{array}$ \\
\hline
\end{tabular}

\section{Kesimpulan}

Dari pembahasan tentang aspek budaya dan ekologis dalam perancangan hunian paska bencana di desa Ngibikan, Yogyakarta, didapat beberapa temuan (1) Desain hunian rekonstruksi di desa Ngibikan merupakan salah satu contoh proses rekonstruksi yang berhasil karena dapat menjawab kebutuhan penghuninya, mewadahi kebiasaan warga, serta responsif terhadap lingkungannya. (2) Dari sisi lingkungan/ekologis, penggunaan material lokal serta pemberdayaan sumber daya yang ada di lingkungan sekitar pemukiman membuat desain hunian ini dapat melekat dengan kondisi lingkungan dan alamnya. Selain bangunan dapat dengan nyaman dihuni karena merespon iklim lokal dengan baik, juga bangunan tidak menimbulkan efek negatif bagi lingkungan sekitarnya. (3) Dari sisi budaya, bentuk hunian yang didesain sesuai dengan bentuk dan prinsip-prinsip arsitektur lokal setempat, serta dilibatkannya masyarakat secara aktif dari tahap perencanaan sampai pembangunan turut membantu menghasilkan desain yang dapat sesuai dan menjawab kebutuhan dan kebiasaan/budaya penghuninya.

Melalui telaah kasus studi dapat disimpulkan bahwa aspek budaya dan ekologis merupakan dua hal yang saling berkaitan dimana keduanya terdapat dalam prinsip perancangan arsitektur tradisional yang merupakan wadah bagi budaya/ kebiasaan masyarakat lokal dan juga sebagai suatu bentuk respon masyarakat terhadap kondisi dan potensi alam yang ada disekitarnya. Oleh karena 
itu dapat dikatakan bahwa aspek budaya dan ekologis merupakan aspek penting dalam perancangan hunian paska bencana agar dapat menjawab seluruh kebutuhan dan kebiasaan penghuninya, menyatu dengan lingkungannya serta membantu dalam usaha menjaga kelestarian arsitektur dan budaya lokal dari ancaman bencana dan pemberian bantuan hunian yang kurang sesuai dengan budaya lokal masyarakatnya.

\section{Daftar Pustaka}

Cowan, Stuart and van de Ryn, Sims. 1996. Ecological Design. USA: Island Press.

Frick, H., dan Suskiyanto, F.X. Bambang. 1998. Dasar-dasar EkoArsitektur. Yogyakarta: Penerbit Kanisius.

Hui, Sam C. M. 1996 (updated 2002). Sustainable Architecture. http://www.arch.hku.hk/research/be er/sustain.htm. Diakses pada November 2016.

Knapp, Ronald G \& Kai Yin Lo., (2005) ,House Home Family: Living and Being Chinese, University of Hawaii Press, Honolulu.

Prijotomo, Josef, 2010. Arsitektur Nusantara Arsitektur Naungan bukan Lindungan Sebuah Reorientasi Pengetahuan Arsitektur Tradisional. ITS Digital Library.

Rapoport, Amos.,1969 House Form and Culture,Englewood Cliffs NJ, University of Wiscosin, Milwaukee.

Schultz, C. N, (1980). Genius Loci: Towards A Phenomenology of Architecture. Rizzoli, New York.

Shim, Brigitte,(2010), On Site review Report, Reconstruction of Ngibikan Village, Yogyakarta, Indonesia. (online) dalam (https://archnet.org/sites/6453/publi cations/ diakses November 2017). 
Jurnal Teknik Arsitektur ARTEKS, Volume. 2, Nomor 2, Juni 2018 ISSN 2541-0598 